\title{
Virtual undergraduate teaching assistantships of pediatrics and social network medical education: a successful experience at an university in the south of Rio de Janeiro
}

\author{
Monitoria virtual de pediatria e educação médica na rede social: uma experiência bem \\ sucedida em uma universidade no sul do Rio de Janeiro
}

Monitoreo virtual de pediatría y educación médica en la red social: una experiencia exitosa en una universidad en el sur de Río de Janeiro

Aléxia Alves Cabral $^{1 *}$, Lorena Araújo Silva Dias ${ }^{1}$, Gabriele Alves dos Anjos ${ }^{1}$, Silvia Souza Salvato ${ }^{1}$, Marcelle Godinho Fonseca ${ }^{1}$, Gabriel José Gerpe Garin Borges ${ }^{1}$, Clarisse Pereira Dias Drumond Fortes ${ }^{1}$.

\begin{abstract}
Objective: To highlight the changes and adaptations resulted from COVID-19 in Medical Undergraduate Teaching Assistantships (UTA) activities at an University in the south of Rio de Janeiro, emphasize the importance of education in health through social networks and enrich the scientific literature with the theme of virtual distance learning in Medicine. Experience report: The adaptation of the UTA to the virtual environment prevented to be interrupted the development of effective communication and teaching skills, which are important bases for medical training, promoting the continuity of teaching, albeit in a limited way. Be that as it may, being an undergraduate teaching assistant in a virtual class leads to the consolidation and detailing of knowledge, providing flexibility in the learning process, encouraging the development of teaching and digital skills, teamwork, use of different resources and collaborative performance. This fact stands out the role of the medical student in the teaching-learning process, especially at a time of new experiences and adaptations. Final considerations: It is necessary to evaluate how medical education has been harmed or benefited by the changes arising from the COVID-19 pandemic and how it will have a long-term impact on medical training.
\end{abstract}

Keywords: COVID-19, Education medical, Online social networking, Pandemics, Students medical.

\section{RESUMO}

Objetivo: Pontuar as mudanças e adaptações realizadas em consequência da COVID-19 nas atividades de monitoria de Medicina em uma Universidade no sul do Rio de Janeiro, enfatizar a importância da educação em saúde por meio das redes sociais e enriquecer a literatura científica com o tema de ensino virtual à distância na Medicina. Relato de experiência: A adaptação do programa de monitoria acadêmica para o ambiente virtual impediu que fosse interrompido o desenvolvimento das habilidades de comunicação efetiva e de docência, que se configuram como bases importantes da formação médica, promovendo a continuidade do ensino, ainda que de forma limitada. Percebe-se que ser monitor em uma disciplina virtual leva à consolidação e detalhamento do conhecimento, proporcionando flexibilidade no processo de aprendizagem, incentivo ao desenvolvimento das habilidades docentes e digitais, trabalho em equipe, uso

${ }^{1}$ Centro Universitário de Volta Redonda, Fundação Oswaldo Aranha (UniFOA), Volta Redonda - RJ.

*E-mail: cabralalx@gmail.com

SUBMETIDO EM: 4/2021

ACEITO EM: 5/2021

PUBLICADO EM: 6/2021 
de diferentes recursos e atuação colaborativa. Tal fato evidencia o papel do estudante de Medicina no processo de ensino-aprendizagem, principalmente, em momento de novas experiências e adaptações. Considerações finais: Torna-se necessário avaliar de que modo o ensino médico saiu prejudicado ou beneficiado pelas mudanças advindas da pandemia da COVID-19 e como isso impactará a longo prazo na formação médica.

Palavras-chave: COVID-19, Educação médica, Redes sociais online, Pandemia, Estudantes de medicina.

\section{RESUMEN}

Objetivo: Señalar los cambios y adaptaciones realizados como consecuencia del COVID-19 en las actividades de seguimiento médico de una Universidad en el sur de Río de Janeiro, enfatizar la importancia de la educación en salud a través de las redes sociales y enriquecer la literatura científica con el tema de enseñanza virtual a distancia en medicina. Informe de experiencia: La adecuación del programa de seguimiento académico al entorno virtual impidió que se interrumpiera el desarrollo de habilidades comunicativas, que son bases importantes para la formación médica, promoviendo la continuidad de la docencia, aunque de forma limitada. Se observa que ser monitor en una disciplina virtual conduce a la consolidación y detalle de conocimientos, brindando flexibilidad en el proceso de aprendizaje, fomentando el desarrollo de habilidades docentes y digitales, el trabajo en equipo, el uso de diferentes recursos y el desempeño colaborativo. Este hecho pone de relieve el papel del estudiante de medicina en el proceso de enseñanza-aprendizaje, especialmente en un momento de nuevas experiencias y adaptaciones. Consideraciones finales: Es necesario evaluar cómo la educación médica se ha visto perjudicada o beneficiada por los cambios derivados de la pandemia de COVID-19 y cómo tendrá un impacto a largo plazo en la formación médica.

Palabras clave: COVID-19, Educación médica, Redes sociales en línea, Pandemias, Estudiantes de medicina.

\section{INTRODUCTION}

The outbreak of Coronavirus Disease 2019 (COVID-19), which started in Chinese territory, affected the world population in several areas, among them economy, health, and educational services. The rapid spread of the virus resulted in a widespread alert, accompanied by social distancing and the closure of commercial establishments, schools and universities. As a result, the education system was challenged to innovate the approach and continue the learning process, ensuring that students continue their studies, despite being on virtual basis (SANHU P e WOLF M, 2020; VERCELLI LCA, 2020; BRASIL, 2020)

Faced with this new scenario, new methods of instruction have been adopted for medical students to supply face-to-face learning. Classes and other curricular activities begun to be taught online, using various platforms, such as Zoom, Microsoft Teams and Google Meet (SANHU P e WOLF M, 2020; GOMES VTS, et al., 2020).

As a way of supporting the development of students' learning, universities in Brazil already used Undergraduate Teaching Assistantships in person, which was adapted to the online education modality. The undergraduate teaching assistant (TA) works together with the professors, guiding the students, organizing the didactic materials, and discussing the topics previously addressed in the classroom (BRANDÃO MGSA, et al. 2017).

This experience is configured as an initiation to higher teaching, in which the TA meets didactic teaching skills, under the guidance of their professors, and acts in a more detailed way in the educational improvement of the participating students. In view of the new readjustments required by the COVID-19 pandemic, the TA develops new skills related to the virtual technology and information environment, contributing to their growth as a student and scholar (AZEVEDO CRL, et al., 2020). 
Based on the scarcity of studies on teaching in the pandemic within the medical education, it is necessary to disseminate information on this extremely relevant topic on the current scenario, which directly influences medical teaching. Thus, the experience report of Pediatrics TAs of the Medicine course at an University Center in the south of Rio de Janeiro, aims to highlight the changes and adaptations resulted from COVID19, emphasizing the importance of education in health through social networks and enrich the scientific literature with the theme of virtual distance learning in Medicine during the pandemic.

\section{EXPERIENCE REPORT}

This is an experience report, descriptive and with a qualitative research approach, carried out from the experiences of the Undergraduate Teaching Assistantships (UTA) of Pediatrics of the Medicine course at this University Centre. The UTA lasts one year and requires a workload of eight hours per week, with four hours of review classes, clarifying doubts, and accompanying and supporting practical and outpatient activities in Pediatrics; and the others are dedicated to planning meetings and studying the topics demanded by the students. All tasks that are the responsibility of the TA are carried out to integrate all their activities without losses, while promoting gains to their academic training. The TA acts in conjunction with the professor guiding the students, organizing the didactic materials, and discussing the topics previously addressed by the professor.

In addition to the UTA activities, a profile was created on the social media Instagram, a free online platform for sharing photos and videos with wide reach, with the objective of expanding the sharing of relevant content on Child and Adolescent Health, both for academic circles and the public.

To build the report, it was used data observed and experienced by the TAs for Pediatrics class, from April to September 2020, at the University Centre in the south of Rio de Janeiro. The evaluation process was conducted through direct observation of the activities carried out on the Microsoft Teams platform and its repercussions.

In view of the readjustments required due to the COVID-19 pandemic, the UTA also relied on the transfer of theoretical activities to the online modality. The digital platform adopted by this University was Microsoft Teams, which manages remote learning and allows the creation of collaborative rooms, with the possibility of chat windows concomitant with screen sharing and activities, making the presentation visible, integrated, and accessible to all participants. Students and professors can work together and synchronously, in real time, creating content and sharing resources in an integrated way, from a single platform. The frequency of student participation is counted through an attendance list generated by the platform's general channel, at the end of the monitoring meetings.

The activities of the UTA of Pediatrics developed for the students are based on the topics addressed by the professor in class and work as a review of the subject that most generated doubts. Academic monitoring is not a substitute for professors, being an activity that benefits both the TA who performs it and the professor, and the students of that class.

The TAs were present in the virtual classroom, created to assist in the explanations, guidance on the activities proposed by the professors and resolution of doubts about theoretical contents of Pediatrics, facilitating the understanding and helping them in their observations. This experience provided the development of didactic skills necessary for the future exercise of the profession, such as, for instance, selfassurance and confidence when passing on information. It also represents a source of constant learning, as the study prior to the explanations of the subject and the setting up of the review class help the TA to explore the previously learned content, complementing the knowledge already acquired on the covered topics.

In view of the virtual teaching modality, used for all the theoretical content of Medicine graduation course during the pandemic, the preparation of review activities of the UTA of Pediatrics was reinforced by visual elements that could captivate the attention of students and make them less monotonous, ranging from 
animations to exam questions or videos, since monitoring tended to happen in late afternoons, when students were already tired of a day full of online activities. The use of aesthetically appealing presentations and the discussion of medical exam questions generated greater interest from the students, which, prior to virtual teaching, did not happen.

Another important point highlighted by the change in the teaching methodology was the possibility of communication by audio or chat only, which made the monitoring environment more uninhibited for both TAs and the participating students. This provided greater knowledge exchanging among the students involved, for they didn't feel as much shyness as they used to do during the in-person activities, and, consequently, it brought greater confidence for the TAs in the explanations and resolution of doubts and, also, for the students to actively participate in the activities and exercises. These changes were most notably observed when practical classes restarted and Pediatrics TAs returned to participate in outpatient and practical activities, showing greater improvement in teaching skills and with greater confidence.

This interaction provided by the virtual distance modality allowed a greater sharing of doubts with all students immediately, due to the easier access to the means of information and communication technology (ICTs), to solve doubts with the reading of articles and other materials together. Such reality also brought the development of more skills involving the technological environment, taking in consideration that the teachinglearning methods are increasingly guided using this type of tool, especially in the academic environment.

Moreover, the use of the digital platform allows meetings to be recorded for later access, ensuring that students can attend it again or, for those who were unable to attend at the time of the activity, are able to attend at further opportunity and, also, take advantage of teaching and review. Thus, there is a greater adherence to the UTA and greater learning for these students.

Another factor that provides a greater adherence is the fact that the students are already at the comfort of their homes, without having to stay at the learning institution beyond the hours of the classes in the course curriculum, in addition to the meetings being scheduled at more flexible times, adapted to the availability of the participants. This allows a better preparation and study of the TAs for the activities, raising the quality of teaching.

In addition to the typical UTA of Pediatrics review meetings, the virtual modality also made it possible to carry out various types of activity, such as Pediatrics simulations created by the TAs themselves, solving and explaining the issues to those interested, and co-participation in events with Academic Leagues and TAs from other classes, to reinforce autonomy, teamwork, and teaching skills. The debate on articles and other materials on a given topic also became broader and, therefore, was able to strengthen the TA-student relationship, along with all the other advantages. Most of the time, the UTA activities were carried out in pairs, which also encouraged teamwork, with the division of tasks of all topics among the Pediatrics TAs, so that everyone had contact with all the topics.

Prior to the pandemic, the UTA was carried in person, in improvised schedules, which resulted in a smaller number of students participating, for being during late afternoon hours, after the end of the in person theoretical classes of the graduation course, or at lunch break. These activities were performed only once, with no possibility of watching them again. Moreover, the fact of being in person left both TAs and students more inhibited and shier, often due to the lack of experience with the teaching practice, leading to less confidence of the TAs during the presentation and less active participation of the students. Furthermore, the activities used to be more subdivided, so that most activities were carried out individually by the TAs, limiting their participation in all topics.

Chart 1 compares the aspects experienced between in person and virtual UTA of Pediatric, revealing that the new modality adopted during the pandemic evinces vantages regarding the possibility to watch the recording of meetings again, schedule flexibility, varied interactions by both audio and chat, greater adherence, more teamwork and development of didactic and virtual teaching skills. 
Chart 1 - Comparative aspects of the Pediatric Undergraduate Teaching Assistantship between in person and virtual teaching modality.

\begin{tabular}{|c|c|}
\hline Before the pandemic & During the pandemic \\
\hline In person & Online \\
\hline Inability to attend meetings again & $\begin{array}{l}\text { Possibility to watch the full recording of meetings } \\
\text { again }\end{array}$ \\
\hline Schedule inflexibility & $\begin{array}{c}\text { Schedule flexibility, adapted to the availability of } \\
\text { TAs and students }\end{array}$ \\
\hline Verbal-only interaction & Interaction by both audio and chat \\
\hline More inhibited and insecure TAs and students & More uninhibited and confident TAs and students \\
\hline $\begin{array}{l}\text { Exposure, solution and discussion of doubts in a } \\
\text { longer way }\end{array}$ & $\begin{array}{l}\text { Immediate exposure, solution and discussion of } \\
\text { doubts }\end{array}$ \\
\hline Lower adherence & Greater adherence \\
\hline $\begin{array}{l}\text { Less contact with Information and Communication } \\
\text { Technologies }\end{array}$ & $\begin{array}{l}\text { Skills development with Information and } \\
\text { Communication Technologies }\end{array}$ \\
\hline $\begin{array}{c}\text { Development of didactic teaching skills and self- } \\
\text { confidence }\end{array}$ & $\begin{array}{c}\text { Development of didactic teaching skills and self- } \\
\text { confidence }\end{array}$ \\
\hline Easier to make presentation dynamic and attractive & $\begin{array}{c}\text { Need for the use of visual aids that captivate } \\
\text { students' attentions }\end{array}$ \\
\hline $\begin{array}{l}\text { Individual work, with distribution of topics among the } \\
\text { TAs }\end{array}$ & $\begin{array}{l}\text { Teamwork, with division of topics of all themes } \\
\text { among the TAs }\end{array}$ \\
\hline Limitation of interaction only at the moment of activity & $\begin{array}{l}\text { Comprehensive interaction, inside and outside } \\
\text { virtual meetings, with positive feedback from } \\
\text { participating students }\end{array}$ \\
\hline
\end{tabular}

Fonte: Cabral AA, et al., 2021.

As of this experience with ICTs in this pandemic period, it was possible to realize the feasibility of success in the virtual meetings of Pediatrics UTA at this University Centre, contrary to what was expected at the beginning of online classes. It is expected that the virtual modality will be further improved so that a hybrid teaching can be possible later, using the advantages of each teaching modality.

\section{DISCUSSION}

The changes and adaptations in the medical education, demanded by the current pandemic scenario, impacted not only universities, but also the training in Medical Residency Programs, for example, which had to renounce many practical experiences in favor of virtual ones, since the presence of COVID-19 abruptly changed the routine of medical care worldwise (SHAH S, et al., 2020; AFONSO DH, et al., 2020). The Medical Residency Programs were also affected, making virtual their curriculum and obtaining good responses from the master students, as it happened with the UTA of Pediatrics (VERCELLI LCA, 2020).

Although it has been a successful experience in most higher education institutions, some impasses of this new model have been addressed by students across the country, such as, for example, the difficulty in understanding how to access virtual platforms, the lengthy adapting process to the new system, technical complications with the internet or electronic devices, increased demand for virtual work and the need to divide attention between household tasks and remote classes (VERCELLI LCA, 2020; OLIVEIRA WA e CHAVES SN, 2020). Regarding the reported experience, we did not observe these difficulties, since the students from this University showed quick adaptation to the remote classes, in addition to a training prior to the beginning of them. 
Virtual teaching has been shown to be useful to promote self-learning and has achieved success similar to traditional didactics, despite the reduction in practical activities (THEORET C e MING X, 2020). This University's UTA is inserted in this context as an important tool for self-improvement and training, both for TAs and for the students participating in the activities, since it represents the continuity of learning being perpetuated among students in the time of a pandemic. Such results are also found in other experiences with virtual monitoring, reiterating the benefits of these activities (AZEVEDO CRL, et al., 2020).

In addition, the development of effective communication skills is one of the foundations of medical training, so that students can put them into practice when exercising the role of TAs (GOMES VTS, et al., 2020). This shows that the adaptation of the UTA to the virtual environment prevented this practice from being interrupted and promoted, once again, the continuity of teaching, albeit in a limited way.

In contrast, the integrative review by Silva MD, et al. (2021) on remote college education demonstrates that the transition from in person to virtual classes presented some impasses, such as limited access to financial and technological resources by students and the difficulty of concentrating for long periods in front of the computer screen. These factors were not found in the reported experience, since all students had access to the ICTs and the duration of the meetings was concise.

From this reality, it can be inferred that education in general will no longer be done in the traditional way, as it was before. The new educational dynamics showed that it is possible to preserve the learning and the link between educator and student, even if virtually, being pointed out as a new educational model for the medical school in the future. Therefore, it is necessary for professors to be able to act in this new scenario, mastering the information technologies used in remote education (OLIVEIRA ES e FREITAS TC, 2020; SILVA BM, 2020; OLIVEIRA SS, et al., 2020). In this context, virtual UTA becomes relevant for the initiation of students in teaching activity, covering contact with ICTs earlier, generating a new time management tool and bringing a new view on the teaching-learning process (AZEVEDO CRL, et al., 2020; CHINELATTO LA, et al., 2020).

Be that as it may, being a TA in a virtual class leads to the consolidation and detailing of knowledge, providing flexibility in the learning process, encouraging the development of teaching and digital skills, teamwork, use of different resources and collaborative performance. Therefore, the experience in this teaching modality contributed to the academic training of the TAs and, also, to the progress of the discipline, favoring communication and development of activities amid the pandemic.

It also becomes explicit that Health Education can be used positively and spread from any social means, whether in person or even over the internet through digital platforms. Regardless of the moment it is used, the sharing of information on social networks is accessible, comprehensive, and more quickly disseminated and, thus, it is shown as a resource that can remain in great evidence.

Such conclusions demonstrate the role of the medical student in the teaching-learning process, especially at a time of new experiences and adaptations. Finally, it is necessary to assess how medical education has been harmed or benefited by the changes arising from the COVID-19 pandemic and how it will have a longterm impact on medical training.

\section{REFERENCES}

1. AFONSO DH, et al. Análise da Associação Brasileira de Educação Médica sobre os desafios da Residência Médica na pandemia da COVID-19. Health Residencies Journal, 2020: 1(3).

2. AZEVEDO CRL, et al. Monitoria acadêmica em uma disciplina semipresencial: relato de experiência. Research, Society and Development, 2020; 9(4): e39942788.

3. BRANDÃO MGSA, et al. Ultrapassando os muros da universidade: a monitoria acadêmica como ferramenta de educação em saúde. Raízes e Rumo, 2017; 5(2): 151-159.

4. BRASIL. Ministério da Educação. Portaria no 343, de 17 de março de 2020. Dispõe sobre a substituição das aulas presenciais por aulas em meios digitais enquanto durar a situação de pandemia do Novo Coronavírus - COVID-19. Diário Oficial da União, 18 mar 2020; Seção 1. Disponível em: http://www.in.gov.br/en/web/dou/-/portaria-n-376-de-3de-abril-de-2020-251289119. Acesso em: 21 set. 2020. 
5. CHINELATTO LA, et al. What You Gain and What You Lose in COVID-19: Perception of Medical Students on their Education. Clinics, 2020; 75: e2133.

6. GOMES VTS, et al. A pandemia da Covid-19: repercussões do ensino remoto na formação médica. Revista Brasileira de Educação Médica, 2020; 44(4): e114.

7. OLIVEIRA ES, FREITAS TC. A educação a distância (EaD) e os novos caminhos da educação após a pandemia ocasionada pela Covid-19. Brazilian Journal of Development, 2020; 6(7): 52860-52867.

8. OLIVEIRA SS, et al. As Escolas Médicas e os desafios da formação médica diante da epidemia brasileira da Covid19: das (in)certezas acadêmicas ao compromisso social. APS em Revista, 2020; 2(1): 56-60.

9. OLIVEIRA WA, CHAVES SN. Os desafios da gestão do ensino superior durante a pandemia da covid-19: uma revisão bibliográfica. Revista de Saúde, 2020; 7(2): 40-58.

10. SANHU P, WOLF M. The impact of COVID-19 on the undergraduate medical curriculum. Medical Education Online, 2020.

11. SHAH S, et al. The Technological Impact of COVID-19 on the Future of Education and Health Care Delivery. Pain Physician, 2020; 23: S367-S380.

12. SILVA BM. Manter-se-á o Ensino Virtual Após a Pandemia de COVID-19? Acta Médica Portuguesa, 2020; 33(6): 440-448.

13. SILVA MD, et al. Coronavírus: consequências da pandemia no ensino superior. Revista Eletrônica Acervo Saúde, 2021; 13(5): e7120.

14. THEORET C, MING X. Our education, our concerns: The impact on medical student education of COVID-19. Medical Education, 2020; 54(7): 591-592.

15. VERCELLI LCA. Aulas remotas em tempos de covid-19: a percepção de discentes de um programa de mestrado profissional em educação. Revista @mbienteeducação, 2020; 13(2): 47-60. 